\section{Commentary: Wrapped or unwrapped Ross procedure?}

\author{
Tirone E. David, MD
}

In this issue of the Journal, Starnes and colleagues ${ }^{1}$ report their experience with the Ross procedure in a relatively small number of patients using 2 distinct techniques: standard aortic root replacement in 71 patients (median follow-up, 15.5 years) and with the pulmonary autograft mounted inside a tubular Dacron in 51 patients (median follow-up, 4.3 years). I may not be the best surgeon to criticize this technique, because I have been "wrapping" dilated aortic roots since I developed aortic valve reimplantation in 1989, and this operation has worked remarkably well in carefully selected patients over the past 30 years. $^{2}$

The probability of reoperation on the pulmonary autograft at 10 years was lower in patients with the pulmonary autograft inside a tubular Dacron graft than in those with a free-standing aortic root, but the latter group had an unusually high reoperation rate at 10 years, which may have included the "learning curve" for the Ross procedure in this report.

The concept of wrapping the pulmonary autograft is not new. ${ }^{3}$ What is new in this report is that the pulmonary autograft was mounted inside a tubular Dacron graft before implantation. The most attractive feature of this technique is that it eliminates the need to alter the anatomy of the aortic root to match that of the pulmonary autograft during the Ross procedure and probably makes the operation simpler. Obviously, one must be careful when reimplanting the coronary arteries and making sure that the opening in the Dacron graft would not compress or kink the coronary arteries.

\footnotetext{
From the Division of Cardiac Surgery of the Peter Munk Cardiac Centre at Toronto General Hospital and the University of Toronto, Toronto, Ontario, Canada.

Disclosure: The author reported no conflicts of interest.

The Journal policy requires editors and reviewers to disclose conflicts of interest and to decline handling or reviewing manuscripts for which they may have a conflict of interest. The editors and reviewers of this article have no conflicts of interest.

Received for publication Jan 28, 2021; revisions received Jan 28, 2021; accepted for publication Jan 29, 2021; available ahead of print Feb 4, 2021.

Address for reprints: Tirone E. David, MD, 200 Elizabeth St, 4N453, Toronto, Ontario, Canada M5G 2C4 (E-mail: tirone.david@uhn.ca).

J Thorac Cardiovasc Surg 2023;165:53

$0022-5223 / \$ 36.00$

Copyright (c) 2021 by The American Association for Thoracic Surgery

https://doi.org/10.1016/j.jtcvs.2021.01.126
}

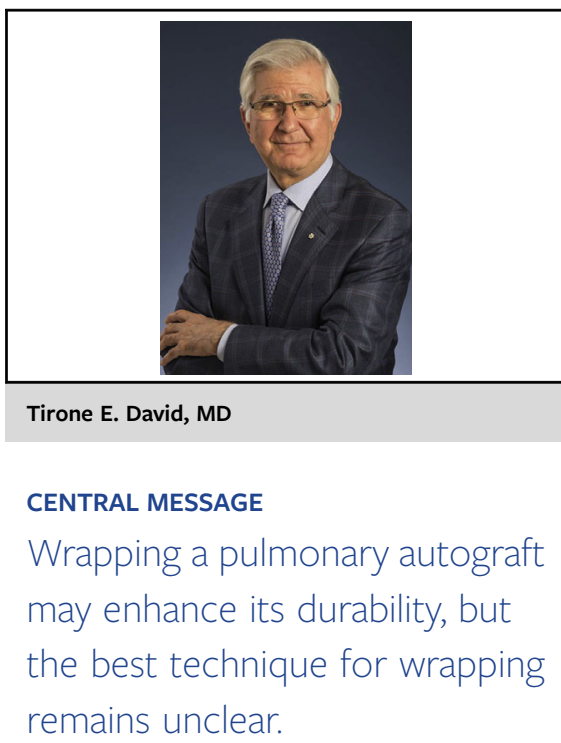

The principal attraction of the Ross procedure is that it replaces the aortic valve with a "living valve" able to adapt itself to the systemic circulation. I wondered whether the autograft remains alive inside a rigid, noncompliant, and avascular structure such as a tubular Dacron graft, and I asked this question of Dr Starnes when he presented this work at the most recent AATS meeting. He indicated that in patients who required aortic valve replacement, the autograft appeared to be viable and well healed inside the Dacron, similar to what happens after aortic valve reimplantation for the treatment of aortic root aneurysm.

I congratulate Starnes and colleagues for this contribution, and note that it is imperative that they continue to monitor the patients who underwent this type of aortic root replacement. I am not going to change the way I do the Ross procedure, because I continue to believe that the best material for wrapping the pulmonary autograft is the patient's native aortic root. Obviously, this is not possible in all patients with bicuspid aortic valves, but it is possible in the vast majority, because these patients frequently have a larger aortic root than pulmonary root.

\section{References}

1. Starnes VA, Elsayed RS, Cohen RG, Olds AP, Bojko MM, Mack WJ, et al. Long term outcomes with the pulmonary autograft inclusion technique in adults with bicuspid aortic valves undergoing the Ross procedure. J Thorac Cardiovasc Surg. 2023;165:43-52.e2.

2. David TE, David CM, Ouzounian M, Feindel CM, Lafreniere-Roula M. A progress report on reimplantation of the aortic valve. J Thorac Cardiovasc Surg. September 5, 2020 [Epub ahead of print].

3. Pacifico AD, Kirklin JK, McGiffin DC, Matter GJ, Nanda NC, Diethelm AG. The Ross operation - early echocardiographic comparison of different operative techniques. J Heart Valve Dis. 1994;3:365-70. 